\title{
Comparative Clinical Efficacy of Guduchyadi Syrup and Guduchyadi Ghanvati in Management of Amlapitta
}

\author{
Research Article
}

\section{Urvee N Solanki ${ }^{*}$, Darshan K Parmar²}

1. P.G Scholar, 2. Assistant professor,

Upgraded Department of Rasa Shastra and Bhaishajya Kalpana, Govt. Ayurved College, Vadodara.

\begin{abstract}
Introduction: Amalpitta is most common problem nowadays. Guduchyadi yoga kwatha was indicated in classics in the management of Amlapitta. Kwatha is very effective but it is unpleasant to some patients. So the kwatha was converted into preferable dosage form as requirement of present era. Material and Method: A Clinical trial was carried out on 60 Patients of Amlapitta aged 20 to 60 years with complaints of Aruchi, Avipaka, Tiktodgar, Amlodgar, Urodaha, Kanthadaha etc., who were registered from OPD of Government Ayurved Hospital, Vadodara. They were equally divided into two groups i.e. Group A- Guduchyadi Syrup given in $20 \mathrm{ml} \mathrm{BD}$ dose and Group B- Guduchyadi Ghanavati given at $500 \mathrm{mg} 2 \mathrm{BD}$ ). Each group was treated for 28 days administered empty stomach. The clinical assessment was carried out on the $28^{\text {th }}$ day and 2 weeks after the 28 days of treatment (after follow up period) for the objective \& subjective parameters and it was seen that both the dosage form Guduchyadi Syrup and Guduchyadi Ghanavati were very effective and cured or markedly relieved the symptoms of Amlapitta. Results: The study shows the effect of Guduchyadi Syrup and Guduchyadi Ghanavati, which led to cure in 16 patients (53.33\%) and $22(73.33 \%)$ patients respectively, and markedly improvement in $12(40 \%)$ and $8(26.67 \%)$ patients affected with Amlapitta disease respectively. Conclusion: Both trial dosage forms of Guduchyadi Yoga, (Group A- Syrup \& Group B- Ghanavati ) relieved the symptoms of Amlapitta and both the formulation have comparatively similar efficacy in the management of Amlapitta.
\end{abstract}

Key Words: Amlapitta, Guduchyadi yoga, Guduchyadi syrup, Guduchyadi ghanavati.

\section{Introduction}

Panchvidha kashaya kalpana are very useful and effective but it comes with some drawbacks in usage, so they are less popular and disagreeable to some patients. Safety, Efficacy, Stability and palatability are four basic requirements of a good drug dosage form.

Nowadays, modern life style and food habits of most of the people in the world are suffering from a common disease, Amlapitta. Peculiarities of this disease are, increased prevalence, vast manifestation of symptoms, requires prolonged dietetic control. If not treated in proper time, it may create major problems and relapses are very common. Guduchyadi yoga containing Guduchi (Tinospora cordifolia Willd.), Khadira (Acacia catechu Willd.), Yastimadhu (Glycyrrhiza glabra Linn.) and Daruharidra (Berberis aristata DC) is given in the kwatha form in the classical textbook for the management of Amlapitta. The Kwatha is one of the Panchvidha kashaya Kalpana having very short shelf

* Corresponding Author:

Urvee N Solanki

Final year PG scholar

Upgraded Department of Rasa Shastra and Bhaisajya

Kalpana, Government Ayurved College,

Vadodara, Gujarat, India

Email Id: urvee92.solanki@gmail.com life which leads to its contamination in a short period of time. Thus it doesn't fulfill basic requirement of a good dosage form. So it was converted into new dosage form as Guduchyadi syrup and Guduchyadi Ghanavati to fulfill requirement of the present era to make available in the acceptable form to the people globally.

\section{Aims and objectives}

Aim: To evaluate efficacy of Guduchyadi yoga in the form of Syrup and Ghanavati.

Objectives:

1.To compare the efficacy of two different dosage forms of Guduchyadi yoga i.e. Guduchyadi Syrup and Guduchyadi Ghanavati in the management of Amlapitta.

\section{Ethical committee clearance and CTRI registration}

As this was a clinical research, Institutional Ethics Committee (IEC) approval was taken prior to initiation of research vide its letter No. GAC/VAD/IEC/ $22 / 2017$ dated 22/09/2017. Study was registered in Clinical Trial Registry of India with no CTRI/ 2018/06/1458.

\section{Materials and Methods \\ Preparation of trial drug}

Raw materials of all the drugs were obtained from Govt. Ayurved Pharmacy, Rajpipla and prepared Guduchyadi Syrup and Ghanavati executing SMP by 
Urvee N Solanki et.al., Clinical Efficacy of Guduchyadi Syrup and Guduchyadi Ghanvati in Management of Amlapitta

preparing a standard Pharmaceutical Performa. Then it was preserved in airtight container.

\section{Selection of Patients}

70 patients of Amlapitta with age 20 to 60 years were enrolled from OPD of Government Ayurved Hospital, Vadodara. Out of which 60 completed the treatment. Total 35 patients were registered in Group A, among them 30 patients were completed and in Group $\mathrm{B}$, total 35 patients were registered among them 30 patients were completed the treatment. Detailed history, complete general and systematic examination was done.

\section{Inclusion criteria}

Patients having age between 20-60 yrs, for selection of patients with classical sign and symptoms of Amlapitta Aruchi, Avipaka, Tiktodgar, Amlodgar, Gurukostha, Shiroruja, Urodaha, Kanthadaha, Antrakujan.

\section{Exclusion Criteria:}

Patients having age less than 20 years and more than 60 years, Patients Age below 20yrs and above 60yrs., Malignant and accelerated Hypertension, Pregnant women, Lactating mothers, Patients of any other severe illness.

Sixty patients were randomly grouped into two groups. Each group consisted of 30 patients and the groups were named as Group A and B. They were administered with Guduchyadi Syrup (group A) and Guduchyadi Ghanavati (group B) for 2 times a day (morning and evening) on empty stomach for 28 days. All patients were advised to follow Pathyapathya.

\section{Assessment scale}

Parameter assessment was carried out by numbering relieves in the symptoms. Evaluation of response in view of the changes in the clinical features, the grading was as below

\section{Result}

Cured

Markedly Improved

Improved

Unimpro ved

Severity increases

Dropped out

\section{Criteria}

$100 \%$ relief in the signs \& symptoms was considered as cured.

$70-99 \%$ relief in the signs \& symptoms was considered as markedly improved. $36-70 \%$ relief in the signs \& symptoms was considered as (moderate) improved . $<35 \%$ relief in the signs \& symptoms was considered as mild improved or Unimproved.

If the patient have increases the sign and symptoms was considered as Severity increased.

If the patients hadn't completed course egularly and discontinued treatment during trial for any reason was considered as Dropped out.

\section{Statistical analysis}

The effect of therapy in both the groups is assessed by applying t-test. The results obtained are considered highly significant for $\mathrm{P}<0.001$, significant for $\mathrm{P}<0.05$, and insignificant for $\mathrm{P}>0.05$.

\section{Observations and Results}

Table no.1 Total number of patients registered

\begin{tabular}{|c|c|c|c|c|}
\hline \multirow{3}{*}{ Type } & No. of & Total & \multirow{2}{*}{} & \multirow{2}{*}{ Patients } \\
\cline { 3 - 4 } & Group A & Group B & & \\
\cline { 3 - 4 } & & 30 & 60 & 85.71 \\
\hline Completed & 30 & 5 & 10 & 14.29 \\
\hline Discontinued & 5 & 35 & 70 & 100 \\
\hline Total & 35 & &
\end{tabular}

In this study, total 70 patients were registered. 60 patients had completed the treatment in two groups. (Table 1)

Table no.2 Percentage wise cardinal signs and symptoms

\begin{tabular}{|c|c|c|c|c|}
\hline \multirow{2}{*}{ Cardinal Signs } & \multicolumn{2}{|c|}{ Group A } & \multicolumn{2}{c|}{ Group B } \\
\cline { 2 - 5 } & No. of Patients & $\%$ & No. of Patients & \% \\
\hline Avipaka & 26 & 86.67 & 29 & 96.67 \\
\hline Aruchi & 25 & 83.33 & 26 & 60 \\
\hline Tiktodgar & 26 & 86.67 & 25 & 83.67 \\
\hline Amlodgar & 28 & 93.33 & 25 & 83.33 \\
\hline Gurukostha & 27 & 90 & 26 & 86.67 \\
\hline Shiroruja & 20 & 66.67 & 16 & 53.33 \\
\hline Kanthadaha & 21 & 70 & 11 & 36.36 \\
\hline Antakujana & 17 & 56.67 & 25 & 83.33 \\
\hline Urodaha & 27 & 90 & \\
\hline
\end{tabular}


International Journal of Ayurvedic Medicine, Vol 11 (2), 261-264

Table no. 3 Comparison between two groups in chief complaints of Amlapitta

\begin{tabular}{|c|c|c|c|c|c|c|c|c|}
\hline \multirow{2}{*}{ Sr. No } & \multirow{2}{*}{$\begin{array}{c}\text { Chief } \\
\text { Complaints } \\
\text { of Amlapitta }\end{array}$} & \multicolumn{2}{|c|}{ Relief in \% } & \multicolumn{2}{|c|}{ SD } & \multirow{2}{*}{ 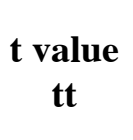 } & \multirow[b]{2}{*}{ Pvalue } & \multirow{2}{*}{$\begin{array}{c}\text { Group A } \\
\text { V/S } \\
\text { Group B }\end{array}$} \\
\hline & & Group A & Group B & Group A & Group B & & & \\
\hline 1 & Avipaka & 88.14 & 98.85 & 1.135 & 0.944 & 0.124 & 0.902 & NS \\
\hline 2 & Aruchi & 98.77 & 87.5 & 0.999 & 1.258 & 1.125 & 0.216 & NS \\
\hline 3 & Tiktodgar & 89.74 & 95.49 & 1.145 & 1.322 & -0.313 & 0.755 & NS \\
\hline 4 & Amlodgar & 81.55 & 92 & 0.937 & 1.281 & 0.459 & 0.648 & NS \\
\hline 5 & Gurukostha & 91.36 & 100 & 1.053 & 1.106 & 1.195 & 0.237 & NS \\
\hline 6 & Shiroruja & 98.41 & 100 & 1.008 & 1.149 & 0.597 & 0.553 & NS \\
\hline 7 & Kanthadaha & 98.81 & 100 & 1.02 & 1.579 & -0.389 & 0.699 & NS \\
\hline 8 & Antakujna & 93.81 & 90 & 0.828 & 0.855 & 1.534 & 0.13 & NS \\
\hline 10 & Urodaha & 89.51 & 96.67 & 1.094 & 1.363 & -3.239 & 0.002 & S \\
\hline
\end{tabular}

Table no. 4 Overall effect of therapy in 60 patients

\begin{tabular}{|c|c|c|c|c|}
\hline Result & $\begin{array}{c}\text { Group A } \\
\text { (no. of patients) }\end{array}$ & \% & $\begin{array}{c}\text { Group B } \\
\text { (no. of patients) }\end{array}$ & \% \\
\hline Cured & 16 & 53.33 & 22 & 73.33 \\
\hline Markedly Improved & 12 & 40 & 8 & 26.67 \\
\hline Moderately Improved & 2 & 6.67 & 0 & 0 \\
\hline Unimproved & 0 & 0 & 0 & 0 \\
\hline Severity increased & 0 & 0 & & 96.71 \\
\hline Overall & & 92.41 & & 0 \\
\hline
\end{tabular}

\section{Group A}

$53.33 \%$ patients had been cured Amlapitta by Guduchyadi Syrup when 40\% patients had markedly improved and $6.67 \%$ had improved moderately symptom of Amlapitta.

\section{Group B}

Guduchyadi Ghanavati had complete cured Amlapitta in $73.33 \%$ patients when $26.67 \%$ patients had markedly improved and $6.67 \%$ had improved moderately.

\section{Overall}

Guduchyadi Syrup and Guduchyadi Ghanavati had exhibited significant result (Group A-92.41\%, Group B-96.71\%) in the management of Amlapitta. A Comparative efficacy between these two groups is not significant $(\mathrm{P}>0.05)$. So both dosage forms of Guduchyadi Yoga are merely similar effective in the management of Amlapitta.
While evaluating the overall effect of therapy, it was observed that none of the patients remained unimproved or severity increased due to medicine.

\section{Discussion}

Nowadays in the modern life style and irregular food habits, many people are suffering from a common disease called Amlapitta. If it is not treated in a proper time, it may cause major problems. Guduchyadi Yoga kwatha has been mentioned in the management of Amlapitta in classics. The kwatha form is less preferable to some patients. Kwatha doesn't complete these criteria as it has very short shelf life about one day. So, it has to be prepared immediately and daily when they have to consume. Further kwatha is nonpalatable because of its bitter and disagreeable taste and patient discontinue medicine. Thus, to overcome these drawbacks the Guduchyadi yoga kwatha was converted into further two dosage forms as Ghanavati and Syrup which are more palatable amd shelf life of Syrup and 
Urvee N Solanki et.al., Clinical Efficacy of Guduchyadi Syrup and Guduchyadi Ghanvati in Management of Amlapitta

Tablet can extend up to 3yrs. Guduchyadi yoga having bitter, astringent and Sweet taste and was found very effective in Amlapiita clinically. It shows that Guduchyadi Syrup and Guduchyadi Ghanavati had exhibited significant result (Group A-92.41\%, Group B-96.71\%) in the management of Amlapitta. A Comparative efficacy between these two groups is not significant $(\mathrm{P}>0.05)$. So both dosage forms of Guduchyadi Yoga are comparatively similar effective in the management of Amlapitta.

\section{Conclusion}

The dosage forms of Guduchyadi yoga that is Guduchyadi Syrup and Guduchyadi Ghanavati was found very effective in the management of Amlapitta individually. Comparative efficacy between Guduchyadi Syrup and Guduchyadi Ghanavati was found similar in the management of Amlapitta.

\section{References}

1. Shree Satyanarayan Shastri Agnivesh CharakSamhita Revised by Charaka Vidhyotini Hindi commentary Reprint year 2016 Chaukhambha
Bharati Academy, Varanasi. Vol-I Cha.su.4/6 Pg.no.67

2. Shri Chakrapanidatta virachit "Chakradatt" commented by Indradev Tripathi; Chapter of Amlapitta; pg no. 266

3. Prabhakar Rao G; Bhaishjya Ratnavali of Kaviraj shri Govind Das Sen commented by shri Raman Prabhakar First edition 2014 Chaukhambha orientalia Vol-II chap.51 pg.no.354

4. Madhavnidan of Madhavkar, $6^{\text {th }}$ edition; Sastu Shahitya Mudranalaya Trust 2013, chap.51 pg no. 668

5. Pandit Hemraj Sharma, Satyapal Bhisagacharya Kashyapsamhita; edition Reprint 2013; Chaukhambha Sanskrit Sansthan - Varanasi. Chap.16/14-15 pg.no.336

6. Pandit Hemraj Sharma, Satyapal Bhisagacharya Kashyapsamhita; edition Reprint 2013; Chaukhambha Sanskrit Sansthan - Varanasi. Chap.16/14-15 pg.no.338

7. Ministry of Ayush: ayush.gov.in: Gazette notification GSR No.789(E) dated 12th Aug.2016 for revising shelf life of ASU Drugs. 